\title{
Evaluation of Tourism Investment Priorities in Zoroastrian Villages of Yazd Province, Iran
}

\author{
Jamal Kheiri*, Ramtin Shohrat Zeinabad, Farhad Tabatabaie \\ Faculty of Management, University of Tehran, Tehran, Iran \\ *Corresponding author: jamalkheiri@yahoo.com
}

\begin{abstract}
Rural tourism is a form of tourism that has received more attention in recent years. Investment in rural tourism can be useful for improving the lives of local community. Among provinces of Iran, Yazd has the potential for development of rural tourism because of its unique cultural and climatic features. In this study, 4 Zoroastrian villages including Rahat Abad, Cham, Mobarakeh and Mazrae Kalantar were studied from different aspects to be prioritized for tourism investment. This study is an applied research that used qualitative and quantitative data. First, through the study of literature and interviews with experts, the weight of the different criteria for investment in rural tourism was determined using AHP technique. Then local people were interviewed and Fuzzy TOPSIS technique was used to measure quantitative indicators. The results show that Mazrae Kalantar received the highest score $(0.73)$ and was the best village for investment. Rahat Abad, Mobarakeh and Cham, respectively, have the next places for tourism investment priorities.
\end{abstract}

Keywords: rural tourism, investment, AHP, Fuzzy TOPSIS, Yazd, Iran

Cite This Article: Jamal Kheiri, Ramtin Shohrat Zeinabad, and Farhad Tabatabaie, "Evaluation of Tourism Investment Priorities in Zoroastrian Villages of Yazd Province, Iran." American Journal of Rural Development, vol. 4, no. 1 (2016): 1-9. doi: 10.12691/ajrd-4-1-1.

\section{Introduction}

In recent years, tourism was an important revenue source in world trade and an important element in improving and adjusting the balance of trade in many countries ([1]: 156). Balance of payment reflects international transactions of each country and provide an important source of data on importance of tourism ([2]: 6). Importance and magnitude of tourism is not limited to its economic, social or cultural branches and many experts believe communications in tourism sector can reduce political tensions between countries and it is also an effective way to achieve peace, friendship and mutual respect between communities ([31]: 121).

Countries are increasingly aware of the fact that in order to maintain their economic situation, they should try to find new ways and initiatives. Although it differs in different areas, but tourism has always been a factor for economic progress (Gay, 1993: 232). Rural tourism is a form of tourism that includes all types of recreational and leisure activities that receive services such as food, accommodation and local products from local residents in a place where according to laws and regulations or in terms of economic and cultural nature of the country, is considered as rural.

From mid-1940s, travel as a necessity of life, was no longer the monopoly of a certain group of society and many planners became fascinated by itas a business activity with long lasting benefits ([14]: 4). After World War II that tourism became highly developed, mass travel of tourists and lack of planning for these travels caused enormous environmental and social damage in some areas especially in less developed regions. To solve problems like this, planning is a valuable tool that should be used ([3]: 166).

One of critical steps of this process is correct and thoughtful locating of tourism areas. This is also an opportunity for governments to take advantage of tourism potential of poor and less developed areas, especially villages. This can reduce the gap in poverty and create more jobs and economic prosperity. Mr. Isaac Jahangirgi, First Vice President of Iran, on October 2014 at the opening ceremony of the international symposium for sustainable tourism said: "Tourism is an activity that import foreign currencies to country and sharing its benefits among all groups of society, will lead to reduction in social gap, fair distribution of incomes and creating more job opportunities" [8]. One of the areas that can be considered for this are villages that have the potential for tourism development. On the other hand, under the adopted resolution by Parliament on 30 October 2014, Government is obliged to give $3 \%$ of the public funds into aids deprivation under Article 180 of the Fifth Development Plan [9].

Among provinces of Iran, Yazd province has the potential for tourism development because of its special cultural and climate features and is one of the top 10 provinces of Iran in regard to priority in tourism investment ([13]: 11). One of the unique features of Yazd is that there are many villages with population who are often Zoroastrian and have the potential for tourism development ([6], 2). 
The purpose of this study is to determine the criteria for tourism investment based on previous studies and interviews with experts and in the next phase, field interviews with local people and then prioritize these four villages based on tourism investment. For doing this prioritization, the technique for order of preference by similarity to ideal solution (TOPSIS) is used.

\subsection{The Necessity of Issue}

Reviewing the necessity of this research can be done from two perspectives. First is necessity to develop the tourism activities themselves and second is the need to check the location for tourism investment priorities.

About importance of tourism as an activity with a variety of effects such as economic, cultural, social etc., we can refer to related international organizations' statistics. According to the latest statistics of World Tourism Organization (WTO) and Tourism Highlight Report 2014, 9 percent of global GDP is directly or indirectly influenced by tourism. 1 job of every 11 jobs in the world is built by tourism industry and the industry's exports in this year have reached 4.1 trillion US dollars. International tourist arrivals worldwide are expected to increase by $3.3 \%$ a year from 2010 to 2030 to reach 1.8 billion by 2030. Also international tourism receipts reached 1159 billion US dollars in 2013 ([33]: 8).

These figures show the importance of tourism in country's economy. This means that countries with tourism potential, has a big advantage for using it in national economy and development.

After discovery and exploitation of oil, Iran's economic structure is highly dependent on oil exports and foreign currency earnings made from it. The efforts done to get out of this situation and non-oil economic policies did not have any results yet. Now, to create a comprehensive and sustainable development and also alternative income sources instead of oil for Iran, we need to use all of country's capabilities. Tourism can be one of the most important tools.

On the other hand, for development of tourism, priorities must be determined. This means for tourism development, which province, city, region or area has the priority for investment. To address this, priority should consider all aspects of economic, environmental, social and cultural impacts. It can have the following benefits:

- Maximum return on investment for investors

- Minimize the negative impacts of tourism development in destination

- Maximize the benefits of tourism development for local community

- Ability to control, manage and forecast tourism demand in different seasons

- Minimize investment risk

- Create templates for the development of tourism in other parts of the country
- Reduce the gap in poverty and promote social justice.

\subsection{Literature Review}

Number of researches that specifically addresses the priorities for investment in tourism are very limited. But there are lots of work in this field.

Generally, investment evaluation methods are either numeric or non-numeric. Non-numerical method is older and has proved inefficient. Numerical methods can be divided into two categories: profitability analysis and scoring methods. Capital return period and internal rate of return of the net present value and average rate of return are some example of profitability analysis methods. Although these methods are efficient in analysis and costbenefit ratio of profit, but since they only consider profitability aspect of investment, they are ineffective in many real problems. To resolve this problem, new scoring models have been developed that are based on specific methods that combine the advantages of several criteria and do the evaluation or selection part ([5]: 42).

Shakeri and Salimi in a study entitled "factors affecting investment in Chabahar Free Zone and prioritizing them using the mathematical technique of AHP”, identified the bottlenecks and barriers to attracting and expanding investment in free zones and provided a clear vision from factors affecting raise and expansion of foreign investment. The results of this paper show that lack of proper implementation mechanisms and strong executive management with $0 / 32$ priority factor is the main issue of Chabahar Free Zone to attract foreign investments ([4]: 96).

In an article entitled "prioritizing tourism exceptional areas for investment and local development in northwestern part of province of Kermanshah ", Mr. Nouri and Taghizadeh were looking to prioritize areas of Uramanat tourism hub at north-western part of Kermanshah province for investment. Data obtained in this study, is the resultof fieldwork and questionnaires and TOPSIS multi-criteria technique was usedfor its analysis. The results show that the transfer of surveyed areas to investors (for investment) had no economic justification and it will be only a waste of resources and energy.

Akbar Pourfaraj in an article entitled "feasibility of investment opportunities in tourism industry (case study: Tarom tourist resort in Zanjan province)”, emphasized that investment is essential for growth and economic development. Hence, sources of funding should be directed to the most productive and efficient sectors. That's why economic and financial investment plans are essential. The results show that implementation of Tarom recreational tourist town projectcannot be justified considering criteria of financial and economic evaluation ([12]: 8).

Other researches in this fieldare mentioned in the table below:

\begin{tabular}{|l|l|l|l|l|}
\hline Article's title & Year & Authors & Goal & Result \\
\hline $\begin{array}{l}\text { Determining the indicator of } \\
\text { economic investment in proper } \\
\text { allocation of facilities to tourism } \\
\text { industry in conditions of } \\
\text { uncertainty }\end{array}$ & 2011 & $\begin{array}{l}\text { Farzad Karimi } \\
\text { Mehdi Zahedi Keyvan }\end{array}$ & $\begin{array}{l}\text { Determiningindexes for optimal } \\
\text { allocation of funds and facilities } \\
\text { for tourism in each province of } \\
\text { Iran using fuzzy multi-criteria } \\
\text { decision making model }\end{array}$ & $\begin{array}{l}\text { Thorasan Razavi, Gilan, Isfahan, } \\
\text { Golestan, Qom, Shiraz and Yazd } \\
\text { were ranked from first to tenth in } \\
\text { regard of investment in tourism. }\end{array}$ \\
\hline $\begin{array}{l}\text { Factors affecting investment in } \\
\begin{array}{l}\text { Aras and prioritizing them based } \\
\text { on analytical hierarchy process } \\
\text { (AHP) }\end{array}\end{array}$ & 2011 & $\begin{array}{l}\text { Mohammad Reza Nahidi } \\
\text { Asgar Azarkasb } \\
\text { Javad Mohammad Nejad } \\
\text { Ebrahim Ali Mohammadi Asl }\end{array}$ & $\begin{array}{l}\text { Determining factors affecting } \\
\text { raising investment in Aras Free } \\
\text { Zone }\end{array}$ & $\begin{array}{l}\text { Factors including amenities, laws } \\
\text { and regulations, policy making, } \\
\text { management, and positioning were } \\
\text { effective in fundraising. }\end{array}$ \\
\hline
\end{tabular}




\begin{tabular}{|l|c|l|l|l|}
\hline $\begin{array}{l}\text { Relationship between tourism } \\
\text { and foreign direct investment in } \\
\text { developing countries }\end{array}$ & 2010 & $\begin{array}{l}\text { Frank Bastan } \\
\text { Davood Behboodi }\end{array}$ & $\begin{array}{l}\text { Causal relation between number } \\
\text { of foreign tourists and } \\
\text { investment }\end{array}$ & This relationship is direct in Iran \\
\hline $\begin{array}{l}\text { Prioritizing and ranking tourism } \\
\text { centers of Ebrahim Abad in Yazd }\end{array}$ & 2013 & $\begin{array}{l}\text { Mohammad Hossein Ramesht } \\
\text { Maryam Feizollahi }\end{array}$ & $\begin{array}{l}\text { Prioritizing and ranking of areas } \\
\text { that have tourism potential }\end{array}$ & $\begin{array}{l}\text { Surveyed areas have the potential } \\
\text { and capability of a geomorphologic } \\
\text { tourism attraction }\end{array}$ \\
\hline $\begin{array}{l}\text { Determining investment } \\
\text { prioritization in ecotourism areas } \\
\text { of Uremia city }\end{array}$ & 2010 & $\begin{array}{l}\text { Imamali Asheri } \\
\text { Bagher Hosseinpour } \\
\text { Taghi Mehdiloo }\end{array}$ & $\begin{array}{l}\text { Determine investment priorities } \\
\text { using social, infrastructural, } \\
\text { security and natural criteria }\end{array}$ & $\begin{array}{l}\text { Prioritization of criteria presented to } \\
\text { investors is in this order:security, } \\
\text { social, infrastructural and natural }\end{array}$ \\
\hline $\begin{array}{l}\text { Identification and prioritization } \\
\text { of factors affecting foreign direct } \\
\text { investment raising using TOPSIS } \\
\text { technique }\end{array}$ & 2013 & $\begin{array}{l}\text { Azam Kazemi } \\
\text { Majid Beyk } \\
\text { Elham Hadian } \\
\text { Fatemeh Hakimi }\end{array}$ & $\begin{array}{l}\text { Identifying factors } \\
\text { affectingraising of foreign direct } \\
\text { investment and ranking them } \\
\text { using TOPSIS technique }\end{array}$ & $\begin{array}{l}\text { including exchange rates, security, } \\
\text { invent, return on investment, } \\
\text { govental and ... }\end{array}$ \\
\hline
\end{tabular}

\section{Material and Method}

With respect to previous studies and the nature of the issue under discussion, the prevailing approach here is descriptive analytic. As of subjectivity, this study is an applied one and documentation, library works and field studies are applied for data collection. In regard of prioritization, among the 4 chosen villages, the data is gathered based on the theoretical aspects and then criteria definitions in tourism development are determined.

According to the study of literatures and also interview with experts, the authors of this article offered the following model:

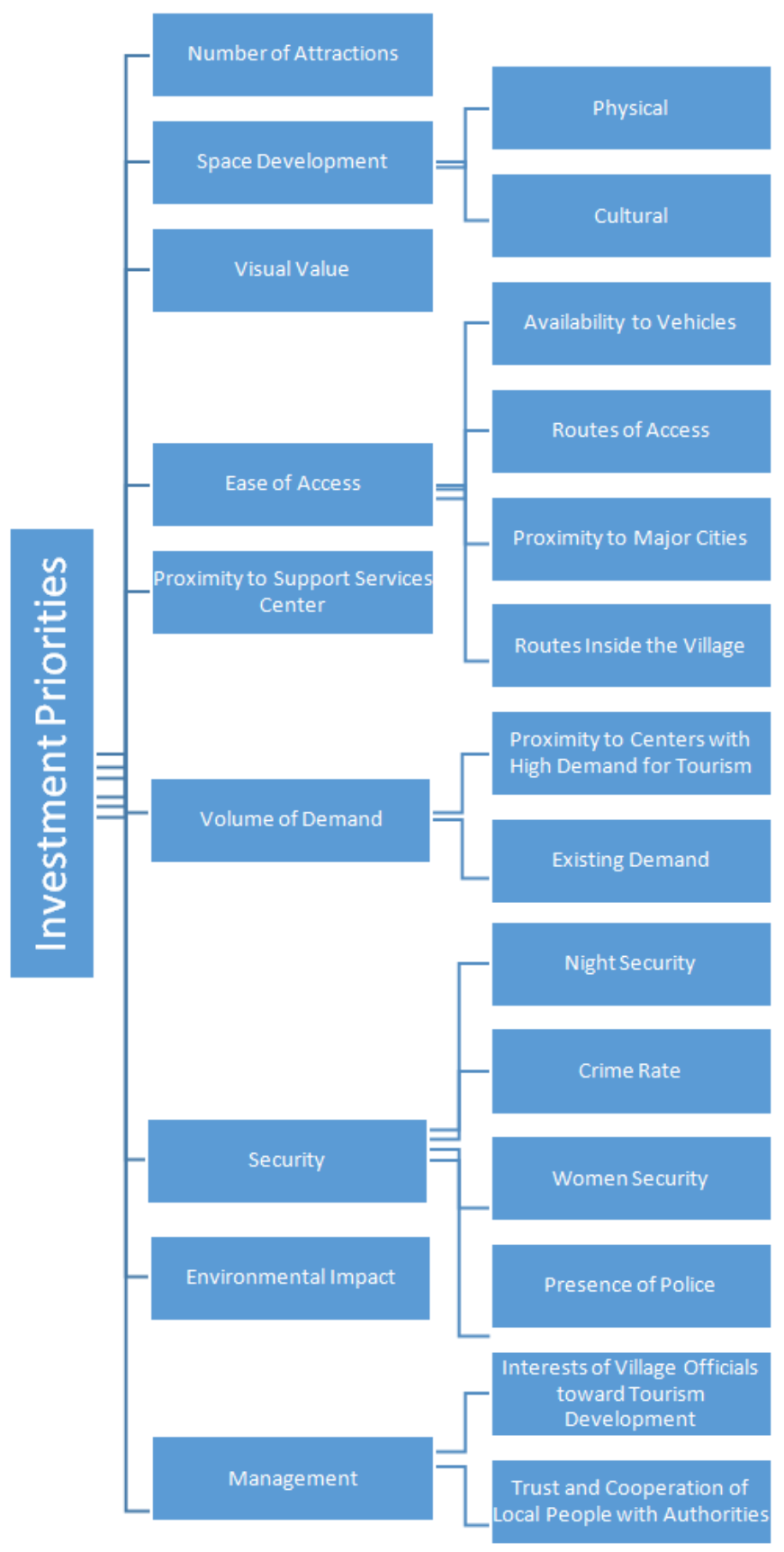

Figure 1. The proposed theoretical model 
This research is an applied research that uses qualitative and quantitative data. The research is based on AHP and TOPSIS methods. In the beginning, researchers did library studies and some interviews with experts. Then the criteria for selecting an area for tourism investment were extracted. This step was done very carefully to make sure all criteria and sub-criteria has features such as comprehensibility, meaningfulness, proportionality with reality, relation to the subject and scientific credibility (Vakili and Hesar, 2013: 4). After outlining the decision tree, weighting of criteria and sub-criteria was done in the range of 0 to 9,using a questionnaire based on AHP method for experts.

Respondents of this questionnaire were selected from the second-year MA tourism students at University of
Tehran by using snowball sampling method and finally 18 correct questionnaires were gathered. Then it was determined how criteria will get scored and which one should be calculated as a quantitative or qualitative value. After that, a questionnaire was designed to determine the score of quantitative criteria and some indicators for qualitative criteria.

In the next step, a visit to villages was done so that questionnaires could be filled by residents of these rural areas and quantitative criteria were measured. In this phase, convenience sampling method was used. In this stage, a five-point Likert scale was used and it was converted to fuzzy numbers using the bellow fuzzy spectrum:

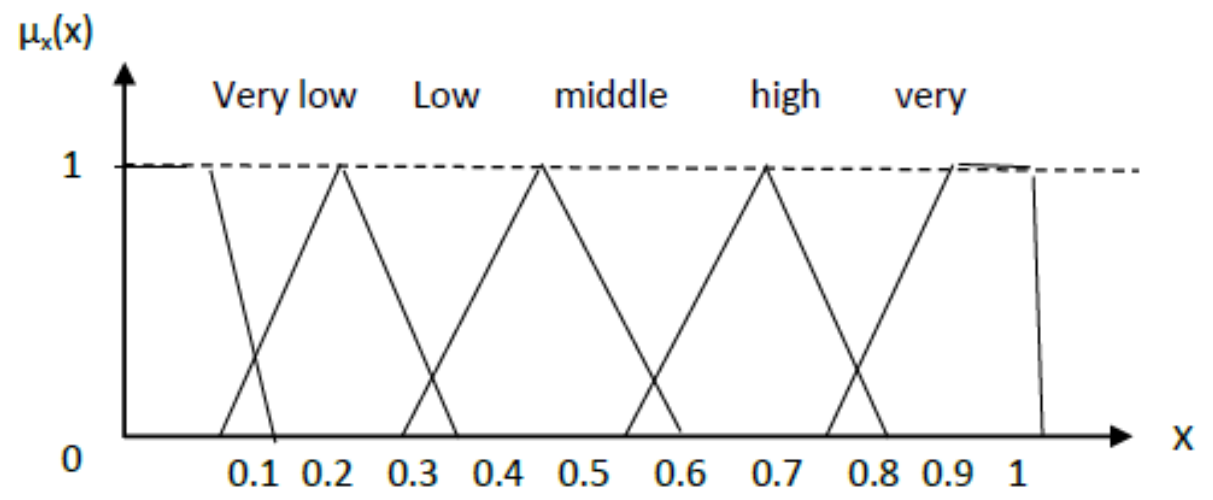

Then data were analyzed based on fuzzy TOPSIS method.

\subsection{TOPSIS Technique}

This method has been proposed in 1992 by Hwang and Yoon and is one of the best models of decision making. The concept of this model is selecting the shortest distance from the positive ideal solution and the farthest distance from the negative ideal solution to solve problems that are faced by multiple decision criteria. This kind of multicriteria decision-making method is useful in examining the real world issues ([10]: 12).

\subsection{AHP Technique}

Analytic Hierarchy Process or AHP is one of the most comprehensive multi-criteria decision-making methods that was developed in the 1970s by Professor Saati. In this technique, it is possible to formulate the problem in a hierarchy. Furthermore, AHP is based on paired comparison and can calculate compatibility and incompatibility. It is also possible to consider individual or group judgments. This method sorts out criteria, options and targets by creating a hierarchical decision tree.

The method of this research is in the table below:

Table 1. Criteria for Tourism Investment

\begin{tabular}{|c|c|c|}
\hline No & Criterion & Definition \\
\hline 1 & Visual Value & $\begin{array}{l}\text { There are certain attractions that have the ability to attract tourists and appeal to them, such as natural, } \\
\text { cultural, historical, or man-made attractions. }\end{array}$ \\
\hline 2 & Number of Attractions & Quantity of tourist attractions. For example, the number of natural and cultural attractions. \\
\hline 3 & Ease of Access & $\begin{array}{l}\text { Access to tourist destinations. Can you reach the desired destination using private or public vehicles, } \\
\text { train or etc.? }\end{array}$ \\
\hline 4 & Available Space for Development & $\begin{array}{l}\text { Available space for development can be divided into two parts of cultural and physical space. } \\
\text { Physical development of tourism in a destination means the space needed for the development of } \\
\text { infrastructures. Like ground (for building and development of resorts), the houses that can be changed } \\
\text { and used for tourists, electricity, gas, internet and etc. The cultural space means mental readiness of } \\
\text { local people about tourism development. Like amount of local people's eagerness for tourism } \\
\text { development; the extent they are interested in training in this area and etc. }\end{array}$ \\
\hline 5 & Proximity to Support Services Centers & $\begin{array}{l}\text { The support services centers are such as police, firefighting, emergency, hospital and etc. In other } \\
\text { words how close a tourist destination is to these services? }\end{array}$ \\
\hline 6 & Volume of Demand & $\begin{array}{l}\text { What is the current extent of demands for tourism destinations and how close is this tourism } \\
\text { destination to the exporting tourism centers? }\end{array}$ \\
\hline 7 & Security & $\begin{array}{l}\text { Crime rates in tourism destinations. Night security, especially for women, and also the presence of } \\
\text { police forces to provide security for the people are its most important aspects. }\end{array}$ \\
\hline 8 & Environmental Impact & $\begin{array}{l}\text { Environmental impact of tourism in destinations. Like effectiveness of waste disposal system, noise } \\
\text { pollution, environmental pollution and etc. }\end{array}$ \\
\hline 9 & Management & $\begin{array}{l}\text { Interest and commitment of village leaders to tourism development and support and association of } \\
\text { local people with them. }\end{array}$ \\
\hline
\end{tabular}




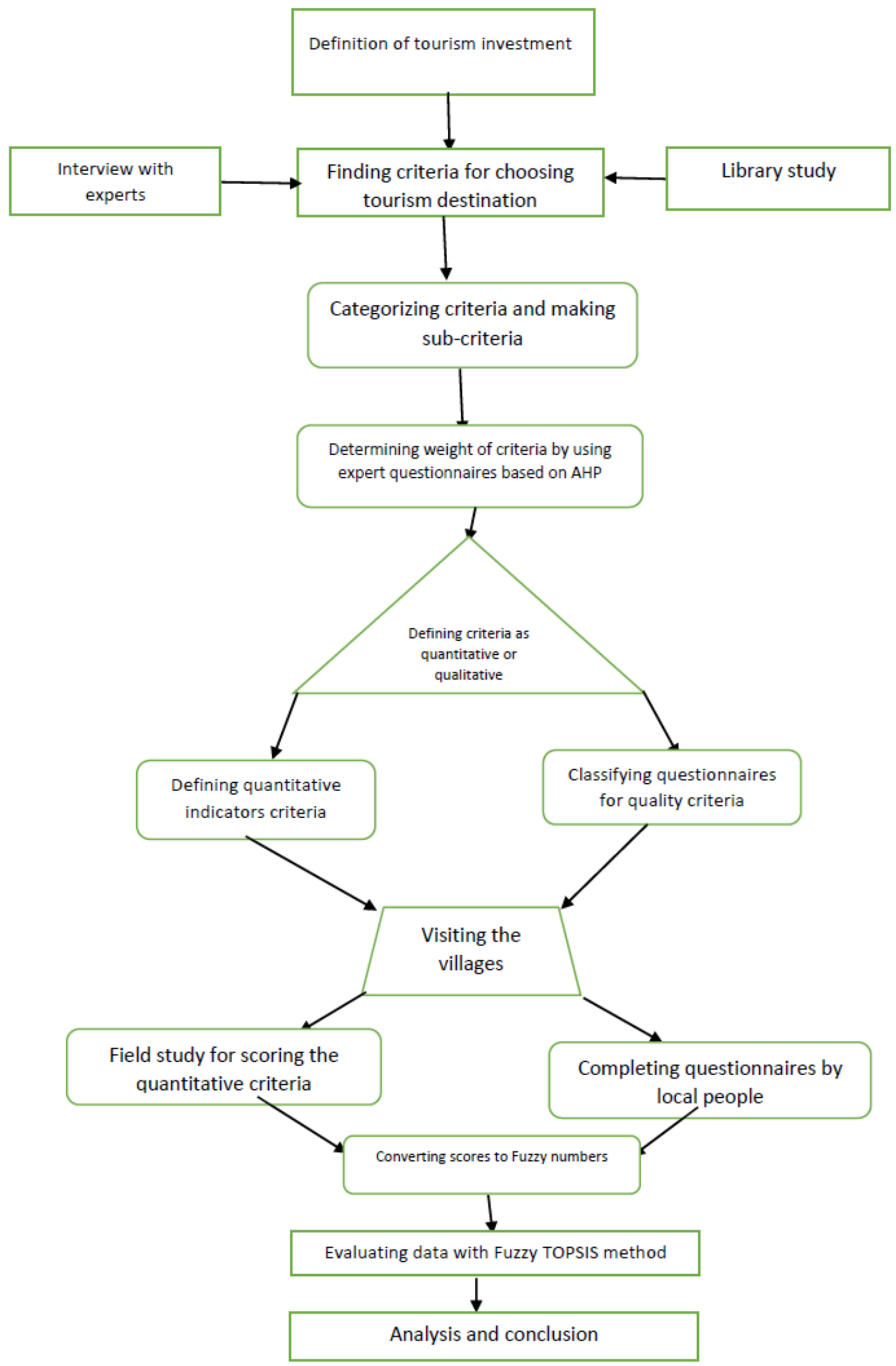

\subsection{Case Study}

\section{Yazd Province}

Among provinces of Iran which has high potential for development of rural tourism, Yazd has a special place
([16]: 5). According to data from the Statistical Center of Iran, based on the last census conducted in 2011, Yazd province has a population of 1,074,428 from which approximately $83 \%$ are urban dwellers. According to data of country division in 2012, the province's total area was 
about 130,000 square kilometers and has 10 city, 19 sectors, 43 rural districts, 21 urban districts and 1144 villages [22]. According to the latest statistics of Iran National Statistics in the winter of 2012, 44\% of workers of this province have worked in service sector, $13 \%$ in agriculture and $43 \%$ in industry.

Researchers chose 4 villages in Yazd (Cham, Rahat Abad, Mobarakeh and Kalantar) based on their potential in tourism. Because to small population of these villages, convenience sampling was used for collecting data. The interviews were conducted in November and December 2015.

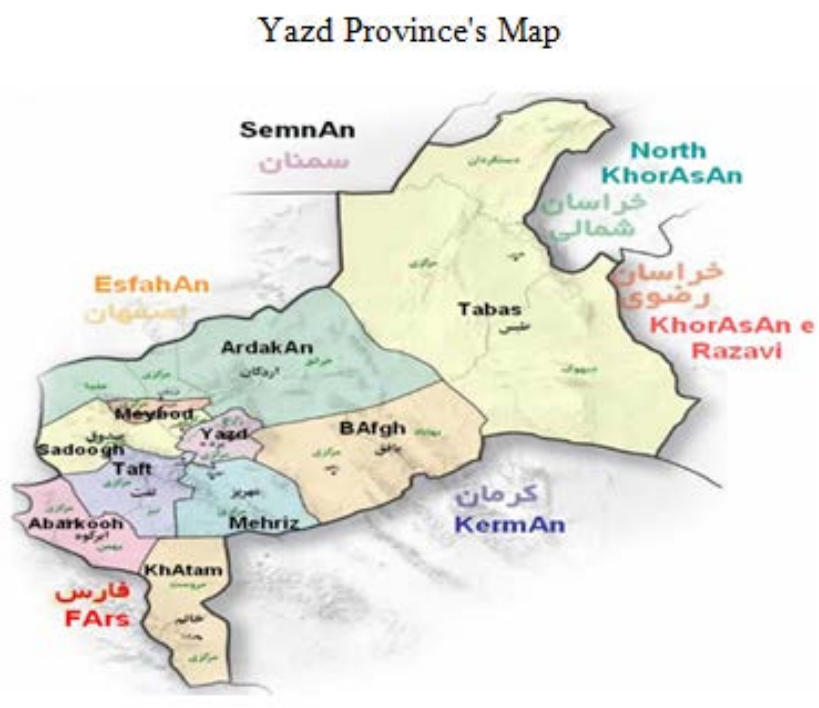

Source: Statistical Center of Iran

\section{General Overview of the Studied Villages} A: Village of Cham

Cham, a village in Taft city of Yazd province, according to the Census of 1385 , only had 11 people and 5 households. The village is located in central part of Pishkuh rural district. City of Taft with an area of 6048 square kilometers, is located 18 kilometers southwest of the province of Yazd. Taft word means "hot" in the Avesta (the Cultural Heritage, Handicrafts and Tourism Yazd Province, 2013).

Zoroastrianism is the religion of local population and there is no Muslim population in this rural area. $70 \%$ of people in this village are literate. Major settlements jobs are such as agriculture, horticulture and animal husbandry. The main products of the village are wheat, barley, alfalfa, sugar beets, turnips, onions, pomegranate and almond.

Water scarcity is a problem in this village. Cham has a historical old cypress tree which is 3 thousand years old. This tree has been registered recently on the list of natural heritage with the number 40 . The tree is in the yard of Zoroastrian fire temple and is 18 meters long (Field Surveys, 2014). According to the Yazd's Head of Cultural Heritage Organization, Cham is a Tourism target village in Yazd province (ISNA, 2012). Cham temple that is related to the late centuries of historical era after Islam has been registered as one of the Iran's national heritages in November 13, 2007 (Deserts of Iran, 2013). 18 people were interviewed in this village for this research.

\section{B: Mobarakeh Village}

Mobarakeh village is located in the Pishkuh rural district. According to the census of 1385, the village has a population of 20 families and 57 individuals. According to the Director General of Taft Cultural Heritage organization, this Village is among the Yazd rural tourism targets. One of the most important monuments in this Zoroastrian village is twin cypresses. This natural attraction dates back 550 years ago and was registered in the list of Iran's natural monuments on November 16, 2009 (ISNA, 2014). 21 people were interviewed in this village for this research.

\section{C: Rahat Abad Village}

Rahat Abad, is one of Zoroastrians villages of Yazd. Muslims also live in the village and the population of them are greater than Zoroastrian population. The living area of Muslims and Zoroastrians is separated into two areas, Muslim and Zoroastrian area. The village has a population of 8 households and 30 people. In This village there are many fruit orchards (Field Studies, 2014). Most of the villagers' job is agriculture and livestock farming. The village has a temple too. 19 people were interviewed in this village for this research.

\section{D: MazraeKalantar Village}

Mazrae Kalantar village is an historic and valuable place in Yazd province. The village has old underground water, water mills and the remains of a historic castle. The castle dates back to a period before Islam. The people of Mazrae Kalantar village speak Persian language with a Yazdi dialect and their religion is Zoroastrianism(The Blog of the World, 1389). 2 or 3 Muslim families live in the village too. The houses in the village have a particular style of architecture. Kalantar is a tourism target village in Yazd Province (Cultural Heritage, Handicrafts and Tourism Organization Yazd, 2014).

Berries, nuts and pomegranates trees, among the houses adds to village's beauty. Around the village are vast plantations which create an environment of freshness and spectacular scenery in spring. Village's temple and a shrine near it, are the village's religious shrines and holy places and in these places, people pray to Ahura Mazda and perform their religious ceremonies (Field Studies, 2014). The most important monuments of village is the historical cistern that was built in 1933. This monument was registered in the Iran National Heritage List on November 13, 2007 [23,24]. 20 people were interviewed in this village for this research.

\section{Result and Discussion}

In this study, using AHP method in range of 0 to 9, weight of criteria and sub-criteria were determined and opinions of 18 tourism experts were calculated and summarized and the results are as follow:

At first, expert opinions were summarized in a matrix by using the geometric mean. Then, the matrix was obtained according to the following equation scale:

$$
\begin{gathered}
A i j=\frac{a_{i j}}{\sum a_{i k}} \\
i=1,2, \ldots, m, j=1,2, \ldots, n, k=1,2, \ldots, n, k=j .
\end{gathered}
$$

Then at the end, each row scores were averaged, and the weight of each criterion was calculated. This was done separately for all criteria that had sub-criteria.

The result is as follow: 


\begin{tabular}{|c|c|c|c|c|c|c|c|c|c|c|}
\hline Criteria & $\begin{array}{l}\text { Visual } \\
\text { Value }\end{array}$ & $\begin{array}{l}\text { Number of } \\
\text { Attractions }\end{array}$ & $\begin{array}{l}\text { Ease of } \\
\text { Access }\end{array}$ & $\begin{array}{c}\text { Space } \\
\text { Development }\end{array}$ & $\begin{array}{l}\text { Proximity } \\
\text { to Support } \\
\text { Services } \\
\text { Center } \\
\end{array}$ & $\begin{array}{l}\text { Volume } \\
\text { of } \\
\text { Demand }\end{array}$ & Security & $\begin{array}{l}\text { Environmental } \\
\text { Impact }\end{array}$ & Management & $\begin{array}{l}\text { Importance } \\
\text { Coefficient }\end{array}$ \\
\hline Visual Value & 1.00 & 2.66 & 2.46 & 1.56 & 2.03 & 2.61 & 0.56 & 1.20 & 0.96 & 0.15 \\
\hline $\begin{array}{l}\text { Number of } \\
\text { Attractions }\end{array}$ & 0.42 & 1.00 & 2.12 & 1.29 & 1.90 & 1.86 & 0.47 & 0.94 & 0.87 & 0.11 \\
\hline Ease of Access & 0.41 & 0.37 & 1.00 & 2.69 & 2.43 & 1.35 & 0.46 & 0.79 & 0.96 & 0.10 \\
\hline $\begin{array}{c}\text { Space } \\
\text { Development }\end{array}$ & 0.53 & 0.77 & 0.37 & 1.00 & 1.47 & 2.13 & 0.49 & 0.93 & 0.86 & 0.09 \\
\hline $\begin{array}{c}\text { Proximity to } \\
\text { Support } \\
\text { Services Center }\end{array}$ & 0.49 & 0.53 & 0.41 & 0.68 & 1.00 & 1.19 & 0.37 & 0.76 & 0.98 & 0.07 \\
\hline $\begin{array}{l}\text { Volume of } \\
\text { Demand }\end{array}$ & 0.38 & 0.54 & 0.74 & 0.47 & 0.84 & 1.00 & 0.50 & 0.62 & 0.79 & 0.06 \\
\hline Security & 1.90 & 2.25 & 2.17 & 2.26 & 2.69 & 2.42 & 1.00 & 2.02 & 1.84 & 0.20 \\
\hline $\begin{array}{c}\text { Environmental } \\
\text { Impact } \\
\end{array}$ & 0.83 & 1.07 & 1.27 & 1.08 & 1.32 & 1.62 & 0.49 & 1.00 & 1.28 & 0.11 \\
\hline Management & 1.04 & 1.15 & 1.04 & 1.17 & 1.02 & 1.27 & 0.54 & 0.78 & 1.00 & 0.10 \\
\hline Score & 7.01 & 10.33 & 11.58 & 12.19 & 14.70 & 15.46 & 4.90 & 9.03 & 9.53 & \\
\hline
\end{tabular}

As you can see, criteria of security, visual value, number of attractions and environmental impact have the most coefficient and criteria of volume of demand and proximity to support service centers have achieved the least important coefficient.

In the expert questionnaire, sub-criteria were also weighted in paired comparison matrixes and finally weight of criteria and sub-criteria were calculated as can be seen in the table below to be used in fuzzy TOPSIS method.

\begin{tabular}{|l|l|l|l|}
\hline Women's security & 0.07 & $\begin{array}{l}\text { Space for physical } \\
\text { development }\end{array}$ & 0.027 \\
\hline The presence of police & 0.03 & $\begin{array}{l}\text { Space forcultural } \\
\text { development }\end{array}$ & 0.062 \\
\hline Environmental impact & 0.11 & Visual value & 0.150 \\
\hline Management's interest & 0.03 & $\begin{array}{l}\text { Public } \\
\text { transportation }\end{array}$ & 0.035 \\
\hline Local people's interest & 0.07 & $\begin{array}{l}\text { Quality of access } \\
\text { route }\end{array}$ & 0.033 \\
\hline Attraction & 0.11 & $\begin{array}{l}\text { Quality of route } \\
\text { inside the village }\end{array}$ & 0.010 \\
\hline $\begin{array}{l}\text { Proximity to support } \\
\text { center }\end{array}$ & 0.07 & Present demand & 0.015 \\
\hline $\begin{array}{l}\text { Proximity to centers of } \\
\text { high demand for tourism }\end{array}$ & 0.04 & Night security & 0.068 \\
\hline $\begin{array}{l}\text { Proximity to big cities of } \\
\text { the province }\end{array}$ & 0.02 & Crime rate & 0.032 \\
\hline
\end{tabular}

In the following, qualitative and quantitative criteria scores were familiarized on TOPSIS technique as fuzzy numbers. In fact, the following matrix is formed that each of its aij is a triangular fuzzy number.

$$
(R)_{m \times n}=\left[\begin{array}{cccc}
\tilde{x}_{i j} & \tilde{x}_{i j} & \cdots & \tilde{x}_{i j} \\
\tilde{x}_{i j} & \tilde{x}_{i j} & \cdots & \tilde{x}_{i j} \\
\cdots & \cdots & \cdots \cdots & \cdots \\
\tilde{x}_{i j} & \tilde{x}_{i j} & \tilde{x}_{i j} & \tilde{x}_{i j}
\end{array}\right]
$$$$
\mathrm{i}=1,2, \ldots, m j=1,2, \ldots, n
$$$$
\tilde{x}_{i j}=\left(l_{i j}, m_{i j}, u_{i j}\right)
$$

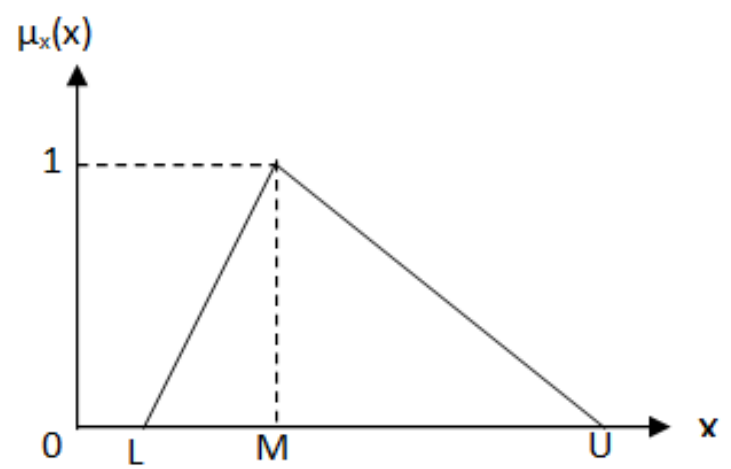

The table below was obtained as table "A" on TOPSIS technique. The scores of this table are result of geometric mean of questionnaire data. Geometric mean was taken from all responses that were given to a question and questionnaire for each village was transformed into a data using this method.

\begin{tabular}{|c|c|c|c|c|c|c|c|c|c|c|c|c|c|c|}
\hline Criteria/village & \multicolumn{3}{|c|}{$\begin{array}{c}\text { Space for physical } \\
\text { development }\end{array}$} & \multicolumn{3}{|c|}{$\begin{array}{c}\text { Space for cultural } \\
\text { development }\end{array}$} & \multicolumn{3}{c|}{ Visual value } & \multicolumn{3}{c|}{ Public transportation } & \multicolumn{2}{c|}{ Quality of access } \\
routes
\end{tabular}

\begin{tabular}{|c|c|c|c|c|c|c|c|c|c|c|c|c|c|c|c|c|c|}
\hline \multicolumn{3}{|c|}{ Quality of routes inside village } & \multicolumn{3}{|c|}{ Present demand } & \multicolumn{3}{|c|}{ Night security } & \multicolumn{3}{|c|}{ Crime rate } & \multicolumn{3}{|c|}{ Women security } & \multicolumn{3}{|c|}{ Presence of police } \\
\hline 0.47 & 0.65 & 0.80 & 0.39 & 0.55 & 1.50 & 0.44 & 0.61 & 0.76 & 0.16 & 0.37 & 0.57 & 0.51 & 0.70 & 0.85 & 0.40 & 0.60 & 0.76 \\
\hline 0.23 & 0.39 & 0.56 & 0.45 & 0.61 & 1.09 & 0.07 & 0.23 & 0.40 & 0.05 & 0.22 & 0.41 & 0.03 & 0.16 & 0.34 & 0.27 & 0.46 & 0.63 \\
\hline 0.35 & 0.53 & 0.70 & 0.39 & 0.55 & 1.06 & 0.20 & 0.36 & 0.54 & 0.10 & 0.30 & 0.51 & 0.32 & 0.52 & 0.69 & 0.43 & 0.61 & 0.78 \\
\hline 0.42 & 0.60 & 0.77 & 0.46 & 0.61 & 1.77 & 0.27 & 0.44 & 0.59 & 0.15 & 0.32 & 0.48 & 0.26 & 0.45 & 0.62 & 0.59 & 0.76 & 0.90 \\
\hline
\end{tabular}




\begin{tabular}{|l|l|l|l|l|l|l|l|l|l|l|l|l|}
\hline \multicolumn{3}{|c|}{ Environmental impact } & \multicolumn{3}{c|}{ Management I'snterest } & \multicolumn{3}{c|}{ Local people's interest } & \multicolumn{4}{c|}{ Attractions } \\
\hline 0.48 & 0.65 & 0.79 & 0.45 & 0.65 & 0.80 & 0.52 & 0.70 & 0.84 & 0.80 & 0.95 & 1.00 \\
\hline 0.33 & 0.44 & 0.57 & 0.22 & 0.46 & 0.65 & 0.47 & 0.65 & 0.80 & 0.80 & 0.95 & 1.00 \\
\hline 0.36 & 0.52 & 0.68 & 0.49 & 0.68 & 0.84 & 0.34 & 0.52 & 0.70 & 0.60 & 0.75 & 0.90 \\
\hline 0.44 & 0.61 & 0.78 & 0.44 & 0.63 & 0.80 & 0.34 & 0.53 & 0.70 & 0.60 & 0.75 & 0.90 \\
\hline
\end{tabular}

\begin{tabular}{|l|l|l|l|l|l|l|l|l|}
\hline \multicolumn{2}{|c|}{ Proximity to support services center } & \multicolumn{3}{|c|}{ Proximity to centers of the high demand for tourism } & \multicolumn{4}{|c|}{ Proximity to big cities of the province } \\
\hline 0.60 & 0.75 & 0.90 & 0.60 & 0.75 & 0.90 & 0.60 & 0.75 & 0.90 \\
\hline 0.60 & 0.75 & 0.90 & 0.60 & 0.75 & 0.90 & 0.60 & 0.75 & 0.90 \\
\hline 0.60 & 0.75 & 0.90 & 0.60 & 0.75 & 0.90 & 0.60 & 0.75 & 0.90 \\
\hline 0.60 & 0.75 & 0.90 & 0.60 & 0.75 & 0.90 & 0.60 & 0.75 & 0.90 \\
\hline
\end{tabular}

Then, data were normalized and in the next step, normalized harmonic matrix was formed. The following formula was used for this step. The weights are obtained from AHP technique.

$$
\begin{aligned}
(R)_{m \times n} & =\left[\begin{array}{cccc}
W_{1} P_{11} & W_{2} P_{12} & W_{3} P_{13} \ldots & W_{n} P_{1 n} \\
W_{1} P_{21} & W_{2} P_{22} & W_{3} P_{23} \ldots & W_{n} P_{2 n} \\
\ldots & \ldots & \ldots \ldots & \ldots \\
W_{1} P_{m 1} & W_{2} P_{m 2} & W_{3} P_{m 3} \ldots & W_{n} P_{m n}
\end{array}\right] \\
\mathrm{i} & =1,2, \ldots, m \quad j=1,2, \ldots, n
\end{aligned}
$$

Logic of TOPSIS technique is based on minimum distance to positive ideal or the most ideal available option, and maximum distance to negative ideal or the worst option. At this stage, by using normalized harmonic matrix, positive and negative ideals were calculated from the following equation:

$$
\begin{aligned}
& R^{*}=\left\{\left(\max _{i} w_{i} p_{i j i}\right)\right\} \\
& R^{-}=\left\{\left(\min _{i} w_{i} p_{i j i}\right)\right\} .
\end{aligned}
$$

In the next step, distance of options to positive and negative ideals was obtained using the following equation:

$$
\begin{aligned}
& d_{i}^{+}=\sqrt{\sum_{j=1}^{n}\left(w_{i} p_{i j i}-R_{j}^{+}\right)^{2}}, i=1,2, \ldots, n \\
& d_{i}^{-}=\sqrt{\sum_{j=1}^{n}\left(w_{i} p_{i j i}-R_{j}^{-}\right)^{2}}, j=1,2, \ldots, m .
\end{aligned}
$$

The next step is to determine the proximity factor that is calculated from the following formula. The option that has the highest proximity factor which is a number between 0 and 1 , is the best option.

$$
C C_{i}=\frac{d_{i}^{-}}{d_{i}^{+}+d_{i}^{-}}
$$

Numbers related to 4 villages that were targets of this study was achieved as following:

\begin{tabular}{|c|c|c|c|}
\hline Village & $\mathrm{d}+$ & $\mathrm{d}-$ & $\mathrm{cl}$ \\
\hline Mazrae Kalantar & 0.04 & 0.11 & 0.73 \\
\hline Cham & 0.11 & 0.05 & 0.29 \\
\hline Mobarakeh & 0.07 & 0.06 & 0.46 \\
\hline Rahat Abad & 0.06 & 0.08 & 0.55 \\
\hline
\end{tabular}

At the end, rank of each village for investment in tourism was obtained as follows:

\begin{tabular}{|c|c|}
\hline Village's name & Rank \\
\hline Mazrae Kalantar & 1 \\
\hline Rahat Abad & 2 \\
\hline Mobarakeh & 3 \\
\hline Cham & 4 \\
\hline
\end{tabular}

The results show that Mazrae Kalantar village is the best choice for investment in tourism. Rahat Abad and Mobarakeh were at the next priorities, respectably, and Cham village could be the last choice. On the other hand, the results obtained suggest that security is the most important selection factor in the region. The visual value, number of attractions and environmental impact, are also very important.

The results also show that Cham, Mobarakeh and Kalantar Farm are facing water shortages. Rates of crimes, particularly theft from homes exist in all villages and providing security must be on the agenda of officials. Cham village has significant attractions but it got low score at safety and environmental impact. Other villages didn't receive a high score in these criteria too.

In comparison to the similar studies, Rahimi and Ranjbar (2012) prioritized eco-tourism attractions in some villages of Charmahal $\mathrm{O}$ Bakhtiari province in Iran. According to their findings, Atishgah, Sar Agha Syed, Hore and Deh cheshme respectively were prioritized based on their tourism potential. Naderi (2014) did the same research in Shirvan town using AHP method. He evaluated capabilities and effective factors in investment in ecotourism areas. The results show that for investors, four important standards are: the security standard with 0/394 coefficient, the natural standard with 0/394 coefficient, social standard with $0 / 134$ coefficient and infrastructure standard with $0 / 088$ coefficient. Also the results show that among the rural ecotourism areas, Galil, Gelyan, and Zoeram has been identified as the best ecotourism areas in Shirvan town for the investment while Mazrae Kalantar was the best village in this research for investing.

\section{Conclusion}

Researchers, according to the results of interviews and questionnaires, came to the conclusion that before investing in these villages, some planning should be done to promote and improve the culture of accepting tourists 
by local people. The rural population are pleased to have the tourists in their villages but they are not eager to participate them at their events and ceremonies. However, most of the tourism attractions of these villages are these events and ceremonies.

\section{References}

[1] Rezavani, A. A. (2010). Geography and Tourism Industry. Tehran: Payame Noor.

[2] Kazemi, M. (2010). Tourism Management. Tehran: Samt.

[3] Zargham Boroujeni, Hamid. (2012). Tourism Development Planning. Tehran: Mahkameh.

[4] Shakeri, A., Salimi, Fereydoun. (2006). "Factors Affecting Investment in Chabahar Free Zone and Prioritizing them Using the Mathematical Technique of AHP” Economic Research Letter, Vol. 6, pp. 95 and 130.

[5] Pahlavani, Ali. (2008). "Prioritizing Investment Using Group Decision Making Hierarchical TOPSIS in Fuzzy Environment", Journal of Technology Management, Volume 1, pp. 35 to 54.

[6] Imani Khoshkhou, Mohammad Hossein; Ayobi Yazdi, Hami. (2010). "Factors Affecting Tourism Destination Brand Equity in the City of Yazd" Journal of Tourism Studies, No. 13, fall 1389, pages 113 to 138.

[7] Badri, Ali; Yari Hesar, Aristotle. (2013). "The Selection of the Exceptional Areas Using Case Study Method: Kohgiluyeh and Boyer Ahmad" Geographical Research Bulletin, Vol. 24, pp. 44 to 55.

[8] Government Information Center of the Islamic Republic of Iran. (Last modified December 16th 2014) http://www.dolat.ir/NSite/FullStory/News/?Serv=0\&Id=250437.

[9] Jamejam Online Press Institute. (The last review of December 15th 2014). http://www.jamejamonline.ir/newspreview/169091631519002293 1.

[10] Noori, G., Taghizadeh, Zahra. (2007). "Prioritizing Tourism Exceptional Areas for Investment and Local Development in Northwestern Part of Province of Kermanshah". Tourism Management Studies, No. 22, pp. 70 and 100.

[11] Soleymani Harooni, Khadija; Khosravipour, Bahman; Baradaran, M; Ghanian, Mansour. (2010). "The Attitude of the Citizens of Rural Tourism Areas toward of the Consequences of Rural Tourism," Journal of Economic Studies and Agricultural Development, Vol. 2, No. 2, pp. 213 to 218.

[12] Pourfaraj, A., Karami, M., Nekouie, Z, Taleb Bidokhti, Zahra. (2012). "Feasibility of Investment Opportunities in Tourism Industry (Case Study: Tarom Tourist Resort in Zanjan Province)," Journal of Industrial Management Studies, Ninth Year, No. 25, Summer 91, pages 181 to 206.

[13] Karimi, F; Zahedi Keivan, M. (2011). "Determining the Indicator of Economic Investment in Proper Allocation Facilities to Tourism Industry in Conditions of Uncertainty," Journal of Economic Studies and Policies, Vol. 19, No. 59, fall 2011, pages 151 to 174

[14] Ghanbari, Yousof. (2013). "Rural tourism, a new approach in the management of rural". Peyke noor, 7th year, Title 3.

[15] Nahidi, M; Azarkasb, Asghar; Motamednejad, J., Alimohammadiasl, Ibrahim. (2011). "Factors Affecting Investment in Aras and Prioritizing them based on Analytical
Hierarchy Process (AHP)” Financial Engineering and Management Securities Journal, Issue 9, Winter 2011.

[16] Makian, Seyyed Nezamo-Din; Naderi Bani, Mahmoud. (2003). "Studying Foreign Tourism in Yazd". Journal of Economic Studies, Issue 62, fall and summer of 2003, pages 195 to 205.

[17] Behboodi, Davood; Bastan, Frank. (2010). "Relationship between tourism and foreign direct investment in developing countries" Financial Engineering and Exchange Management Journal, Issue 9, winter 2010.

[18] Ramesht, M. H.; Feizollahi, Maryam. (2013). "Prioritizing and Ranking Tourism Centers of Ebrahim Abad in Yazd". Journal of Spatial Planning (Geography), No. 2, summer 2013.

[19] Asheri, Emamali; Hosseinpoor, B., Mehdi Lou, T. (2010). "Determining Investment Prioritization in Ecotourism Areas of Uremia City." Journal of Geography and Regional Planning, No. 1, spring and summer of 2010.

[20] Kazemi, A.; Baik, M.; Hadian, Elham; Hakimi, Fatima. (2013). "Identification and Prioritization of Factors Affecting FDI Raising using TOPSIS Technique». Journal of Fiscal and Economic Policies, No. 4, Winter 2013.

[21] Gee, Chuck Y. and Fayos Sola, Eduardo (2011), Tourism in Global Perspective, Translated by Ali Parsian and Mohammad Arabi, Tehran: Center of Cultural Studies. Seventh Edition.

[22] Iran National Statistics Center. (2013). http://www.amar.org.ir/Default.aspx?tabid=1713.

[23] Wikipedia Encyclopedia (December 12th 2014); The Article of Cham Village: http://fa.wikipedia.org

[24] Wikipedia Encyclopedia (December 12th 2014); The Article Mobarakeh Village (Taft): http://fa.wikipedia.org

[25] Parsa, Manny. "Cham, Tourism Target Village of Taft." (April 9th 2013). Review December 12th 2014. http://isna.ir/fa/news/92012006159/\%DA\%86\%D9\%85\%D8\%B1 \%D9\%88\%D8\%B3\%D8\%AA\%D8\%A7\%DB\%8C\%D9\%87\%D8\%AF\%D9\%81\%DA\%AF\%D8\%B1\%D8\%AF\%D8\%B4\%DA\%AF\%D8\%B1\%D B\%8C-\%D8\%AA\%D9\%81\%D8\%AA.

[26] Website of Iran's Deserts. (December 12th 2014); The Article of Cham Temples, Taft: http://www.irandeserts.com.

[27] Wikipedia Encyclopedia (December 10th 2014); The Article of Mobarakeh Village: http://fa.wikipedia.org.

[28] Wikipedia Encyclopedia (December 11th 2014); The Article of Kalantar Farm's Cistern: http://fa.wikipedia.org

[29] Blog of Iran and the World. (Reviewed in December 13th 2014). http://asiye2010.blogfa.com/post-104.aspx

[30] Portal of Cultural Heritage, Handicrafts and Tourism Administration of Yazd Province. (Revision December 9th 2014). http://yazdcity.ir/SC.php?type=component_sections\&id=31\&t2=D T\&sid $=588$

[31] Edgel, Darid, l. (1990), International Tourism Policy. Publisher: Ran No Strand, Rein Hard, USA.

[32] Meredith, J.R. and Mantle, S.J. (2003) Project Management: A Managerial Approach, New York, John Wiley.

[33] The World Tourism Organization. (2014). "Tourism Highlight Report».

[34] Rahimi, D. Ranjbar, M. (Prioritization of Eco-tourism Attractions (The target villages of Charmahal O Bakhtiar province). Urban Regional Studies and Research Journal. $4^{\text {th }}$, No 14 , University of Isfahan, 2012.

[35] Naderi, Ramezan. (2014). the evaluation of capabilities and effective factors on investment in the ecotourism areas inshirvan town by ahp method. Indian Journal of Fundamental and Applied Life Sciences. Vol 4, 2014. 